\title{
Available phosphorus levels in diets for pigs with high genetic potential for lean meat deposition kept in thermoneutral environment from 15 to $30 \mathrm{~kg}$
}

\section{Leandro Alebrante ${ }^{1}$, Juarez Lopes Donzele ${ }^{2}$, Rita Flávia Miranda de Oliveira ${ }^{2}$, Alysson Saraiva $^{3}$, Simone Eliza Facioni Guimarães ${ }^{2}$, Aloízio Soares Ferreira ${ }^{2}$}

\author{
1 Mestrando em Zootecnia, UFV. Bolsista CAPES. \\ 2 DZO, UFV \\ ${ }^{3}$ Doutorando em Zootecnia, UFV.
}

ABSTRACT - It was used 72 pigs, 36 castrated males and 36 females, with initial weight of $14.97 \pm 0.36 \mathrm{~kg}$ to evaluate levels of dietary available phosphorus (aP). The animals were distributed in a completely randomized block design, with six levels of aP $(0.107 ; 0.214 ; 0.321 ; 0.428 ; 0.535$ and $0.642 \%)$, six replicates and two animals (one castrated male and one female) per experimental unit. Air temperature and relative humidity in the room were kept at $24.5 \pm 1.2^{\circ} \mathrm{C}$ and $76.3 \pm 8.5 \%$, respectively. The levels of aP influenced both daily feed intake and daily weight gain, which increased in a quadratic way up to the estimated levels of $0.420 \%$ and $0.443 \%$, respectively and feed conversion, which improved in a quadratic manner up to the estimated level of $0.461 \%$. It was observed the effects of levels of aP on quantity of phosphorus and ash in the bone, which increased in a quadratic manner up to the estimated levels of $0.525 \%$ and $0.520 \%$, respectively. Levels of Ap affected daily protein deposition in the carcass, which increased in a quadratic way up to the estimated level of $0.394 \%$. There was no effect of levels of aP on daily fat carcass deposition. Levels of aP that provided the best results for daily weight gain, feed conversion and bone mineralization in swines with high genetic potential for lean meat kept in thermoneutral environment, from 15 to $30 \mathrm{~kg}$ are $0.443,0.461$ and $0.525 \%$, respectively, corresponding to estimated daily intakes of $5.25,5.45$ and $6.14 \mathrm{~g}$ of aP.

Key Words: genotype, minerals, requirement, swine, temperature

\section{Níveis de fósforo disponível em rações para suínos de alto potencial genético para deposição de carne magra mantidos em ambiente termoneutro dos 15 aos $30 \mathrm{~kg}$}

RESUMO - Foram utilizados 72 leitões, 36 machos castrados e 36 fêmeas, com peso inicial de 14,97 \pm 0,36 kg para avaliar níveis de fósforo disponível (Pd). Os animais foram distribuídos em delineamento experimental de blocos ao acaso, com seis níveis de Pd $(0,107 ; 0,214 ; 0,321 ; 0,428 ; 0,535$ e 0,642\%), seis repetições e dois animais (um macho castrado e uma fêmea) por unidade experimental. A temperatura interna da sala foi mantida em $24,5 \pm 1,2^{\circ} \mathrm{C}$ e a umidade relativa do ar em 76,3 \pm 8,5\%. Os níveis de Pd influenciaram o consumo de ração diário e o ganho de peso diário, que aumentaram de forma quadrática até os níveis estimados de 0,420 e 0,443\%, respectivamente, e a conversão alimentar, que melhorou de forma quadrática até o nível estimado de 0,461\%. Verificou-se efeito dos níveis de Pd sobre a quantidade de fósforo e cinzas no osso, que aumentou de forma quadrática até os níveis estimados, respectivos, de 0,525 e 0,520\%. Os níveis de Pd melhoraram a deposição diária de proteína na carcaça, que aumentou de forma quadrática até o nível estimado de 0,394\%, e não afetaram a deposição diária de gordura na carcaça. Os níveis de Pd que proporcionam os melhores resultados de ganho de peso, conversão alimentar e mineralização óssea de suínos de alto potencial genético para deposição de carne magra mantidos em ambiente termoneutro na fase dos 15 aos $30 \mathrm{~kg}$ são respectivamente 0,443; 0,461 e 0,525\%, que correspondem a consumos diários estimados de 5,25; 5,45 e 6,14 g de fósforo disponível.

Palavras-chave: exigência, genótipo, minerais, suínos, temperatura

\section{Introduction}

The constant search for greater efficiency in swine production combined with the need to offer a product adequate to consumer preference has directed genetic research to develop pigs with a high potential for lean growth.

Among the main characteristics of these pig strains are the high growth performance and greater carcass yield 
obtained mainly through changes in the pattern of body growth, because these animals have a higher daily rate of protein deposition rather than fat (Correa et al., 2006). However, modifications in the synthesis and deposition of body tissues can result in changes in the voluntary feed intake and nutrient requirements of pigs. A nutrient requirement that has been found to vary according to the genetic potential of pigs is phosphorus (Saraiva et al., 2009).

Besides genetics, the thermal environment in which animals are subjected can also influence performance of the animals and, consequently, the demand for nutrients (Manno et al., 2005). Nevertheless, few studies have related the influence of the thermal environment where pigs are raised and the phosphorus requirements of these animals.

Phosphorus is the second most abundant mineral in the animal organism and its highest concentration is found in the bone tissues (80\%) where, together with calcium, it is responsible for the formation and maintenance of bone structure (Underwood \& Suttle, 1999). Because of its connection to the energy metabolism (storage and transfer through adenosine triphosphate) phosphorus is also important for the growth of muscle tissue, which quantitatively constitutes the second largest body reserve of this mineral (Stahly, 2007).

Pigs during the initial phase of growth prioritize the development of both muscle and bones in relation to lipids (Shields et al., 1983). Because phosphorus is a nutrient required for the synthesis and formation of these tissues, it is necessary to determine the nutritional phosphorus requirement of the present genotypes in the initial phase of growth.

Thus, the objective of this study is to evaluate available phosphorus (aP) levels in diets for pigs with a high genetic potential for lean growth, kept in a thermoneutral environment, from 15 to $30 \mathrm{~kg}$.

\section{Material and Methods}

This study was conducted from October to December 2008. Seventy-two commercial hybrid pigs, 36 castrated males and 36 females, with an initial body weight of $14.97 \pm 0.36 \mathrm{~kg}$ were used. Pigs were allotted in a completely randomized block design with six aP levels $(0.107,0.214$, $0.321,0.428,0.535$ and $0.642 \%$ ), six replicates and two pigs (one castrated male and one female) per experimental unit which was represented by the cage. The relationship and initial body weight of pigs were considered in the formation of the blocks.

The animals were housed in suspended metal cages, with wired mesh floor and sides, equipped with semi- automatic feeders and nipple drinkers, located in a concrete building with a concrete floor and lowered wood roof. The temperature inside the room was kept at $24^{\circ} \mathrm{C}$.

The thermal environment in the room was monitored three times a day (7:00 a.m., 12:00 a.m. and 5:00 p.m.) using a set of thermometers (maximum and minimum, dry and wet bulb and black globe) placed in an empty cage in the middle of the room, and at half the height of the body of the pigs. These data were then converted to the black globe humidity index, according to Buffington et al. (1981).

Experimental diets (Table 1) were a corn/soybean-based meal supplemented with minerals, vitamins and amino acids to meet the requirements of piglets in the initial growth phase (15 to $30 \mathrm{~kg}$ ), as defined by Rostagno et al. (2005) for all nutrients, except phosphorus. The aP levels were obtained through the inclusion of dicalcium phosphate in place of kaolin, resulting in diets with 0.107 , $0.214,0.321,0.428,0.535$ and $0.642 \%$ aP. Industrial amino acids were added to diets to keep the relationship among digestible lysine and the other digestible amino acids according to the ideal protein concept for this animal category recommended by Rostagno et al. (2005).

Pigs were fed ad libitum and water was provided throughout the experimental period (25 days). Daily feed waste was manually collected and weighed at the same time, and animals were weighed at the beginning and end of the experimental period to calculate the average daily feed intake, average daily gain, feed conversion and phosphorus intake.

On the first day of the experimental period, each piglet received $0.5 \mathrm{~mL}$ of a commercial antihelmintic ivermectin (1\%) injected subcutaneously.

Pigs remained on trial until they reached an average of $31.24 \pm 2.53 \mathrm{~kg}$ and then fasted for a period of 24 hours. After fasting, one pig from each experimental unit with a final body weight closest to $30 \mathrm{~kg}$, regardless of sex, was stunned and immediately exsanguinated. Carcasses were then opened and eviscerated.

An additional group of five pigs weighing $15.55 \pm 0.75 \mathrm{~kg}$ were euthanized following the same procedure as the experimental animals to determine the carcass composition at the beginning of the experiment.

Eviscerated carcasses with no blood were divided longitudinally and the left side of each carcass (including head and feet) was crushed for 15 minutes by a commercial cutter $30 \mathrm{HP}$ and $1775 \mathrm{rpm}$. Afterwards, crushed and homogenized samples were taken and stored at $-12^{\circ} \mathrm{C}$.

Samples were thawed at room temperature for a period of 24 hours and then oven-dried at $65^{\circ} \mathrm{C}$ for 72 hours. Because of the high fat concentration, samples were defatted 
Table 1 - Composition and nutritional values of experimental diets (proximate values)

\begin{tabular}{|c|c|c|c|c|c|c|}
\hline \multirow[t]{2}{*}{ Item } & \multicolumn{6}{|c|}{ Dietary aP levels (\%) } \\
\hline & 0.107 & 0.214 & 0.321 & 0.428 & 0.535 & 0.642 \\
\hline Corn & 62.011 & 62.011 & 62.011 & 62.011 & 62.011 & 62.011 \\
\hline Soybean $45 \%$ & 32.000 & 32.000 & 32.000 & 32.000 & 32.000 & 32.000 \\
\hline Soybean oil & 1.810 & 1.810 & 1.810 & 1.810 & 1.810 & 1.810 \\
\hline Dicalcium phosphate & - & 0.577 & 1.156 & 1.734 & 2.312 & 2.891 \\
\hline Limestone & 1.837 & 1.467 & 1.098 & 0.730 & 0.360 & - \\
\hline Kaolin & 1.200 & 0.993 & 0.783 & 0.573 & 0.365 & 0.146 \\
\hline Salt & 0.456 & 0.456 & 0.456 & 0.456 & 0.456 & 0.456 \\
\hline Vitamin premix ${ }^{1}$ & 0.100 & 0.100 & 0.100 & 0.100 & 0.100 & 0.100 \\
\hline Mineral premix ${ }^{2}$ & 0.050 & 0.050 & 0.050 & 0.050 & 0.050 & 0.050 \\
\hline Growth promoter ${ }^{3}$ & 0.075 & 0.075 & 0.075 & 0.075 & 0.075 & 0.075 \\
\hline Growth promoter ${ }^{4}$ & 0.030 & 0.030 & 0.030 & 0.030 & 0.030 & 0.030 \\
\hline L-lysine $\mathrm{HCl}$ & 0.282 & 0.282 & 0.282 & 0.282 & 0.282 & 0.282 \\
\hline DL-methionine & 0.073 & 0.073 & 0.073 & 0.073 & 0.073 & 0.073 \\
\hline L-threonine & 0.066 & 0.066 & 0.066 & 0.066 & 0.066 & 0.066 \\
\hline BHT (butylhydroxytoluene) & 0.010 & 0.010 & 0.010 & 0.010 & 0.010 & 0.010 \\
\hline \multicolumn{7}{|l|}{ Calculated composition } \\
\hline Metabolizable energy (kcal/kg) & 3250 & 3250 & 3250 & 3250 & 3250 & 3250 \\
\hline Crude protein $(\%)^{5}$ & 19.981 & 19.981 & 19.981 & 19.981 & 19.981 & 19.981 \\
\hline Digestible lysine $(\%)^{5}$ & 1.146 & 1.146 & 1.146 & 1.146 & 1.146 & 1.146 \\
\hline Digestible met + cyst $(\%)^{5}$ & 0.641 & 0.641 & 0.641 & 0.641 & 0.641 & 0.641 \\
\hline Digestible threonine $(\%)^{5}$ & 0.721 & 0.721 & 0.721 & 0.721 & 0.721 & 0.721 \\
\hline Sodium (\%) & 0.200 & 0.200 & 0.200 & 0.200 & 0.200 & 0.200 \\
\hline Calcium (\%) & 0.800 & 0.800 & 0.800 & 0.800 & 0.800 & 0.800 \\
\hline Total phosphorus analyzed (\%) & 0.327 & 0.415 & 0.533 & 0.655 & 0.745 & 0.835 \\
\hline Available phosphorus (\%) & 0.107 & 0.214 & 0.321 & 0.428 & 0.535 & 0.642 \\
\hline
\end{tabular}

by a petroleum ether procedure using Soxhlet equipment for 4 hours. Dried and defatted samples were ground and packed into identified glass jars for later laboratory analysis. The water and fat removed during sample preparation were considered for correction of the values for the subsequent analysis.

The chemical analysis of protein and lipid from the carcass samples were performed at the Laboratório de Nutrição Animal of the Departamento de Zootecnia, according to the techniques described by Silva (1990).

The deposition of protein and fat in the carcass was measured by comparative criteria among the carcasses of the first group of animals with body weight of $15.55 \pm 0.75 \mathrm{~kg}$ and the second group of animals, according to the methodology proposed by Donzele et al. (1992).

The front foot from the right side of each carcass was collected, placed in an aluminum container with water and boiled to soften the skin and muscle around the bones to remove the third metacarpal.

Metacarpals were dissected and oven-dried at $65^{\circ} \mathrm{C}$ for 72 hours. The dried bones were then crushed and defatted following a petroleum ether procedure using Soxhlet equipment for 3 hours.
The diet levels of phosphorus and concentrations of calcium, phosphorus and ash in the bones were analyzed by Rodes Química Cajati LTDA (Cajati, SP).

The statistical analysis of the performance data, bone parameters and daily carcass protein and fat deposition was performed using the procedures for analysis of variance and regression contained in the System for Statistical and Genetics Analysis (UFV, 2000).

The requirement of aP was obtained based on the results of daily weight gain, feed conversion, bone parameters and daily deposition of protein and fat in the carcass using linear, quadratic or linear response plateau models, according to the best model adjustment for each variable.

\section{Results and Discussion}

During the experimental period, the temperature in the room was kept at $24.5 \pm 1.2^{\circ} \mathrm{C}$, the relative humidity at $76.3 \pm 8.5 \%$ and the black globe temperature at $25.8 \pm 1.2^{\circ} \mathrm{C}$ with calculated black globe humidity index (BGHI) values of $74.3 \pm 1.79$. The average air temperature $\left(24.5^{\circ} \mathrm{C}\right)$ 
observed in this study was within the thermoneutrality range of $18-28^{\circ} \mathrm{C}$ proposed by Coffey et al. (2000) for this animal category and the calculated value of BGHI was close to that observed (71.1) by Manno et al. (2005) in a study with pigs from 15 to $30 \mathrm{~kg}$ kept in a thermoneutral environment.

The levels of aP influenced $(P<0.01)$ the average daily feed intake (ADFI) (Table 2), which increased quadratically to the estimated level of $0.420 \%$ (Figure 1 ). The significant variation in the voluntary feed intake of pigs in the initial phase of growth by increasing aP levels in the diets was also observed by Saraiva et al. (2009). By contrast, Hittmeier et al. (2006) found no effect of phosphorus level on the ADFI of growing pigs. One factor that might explain the variation in results observed among studies is the calcium:phosphorus (Ca:P) relationship in the diets (Reinhard \& Mahan, 1986). Data of the present work showed that either deficiency or excess of phosphorus negatively affected feed intake, implying that pigs are sensitive to inadequate levels of this mineral in their diets.

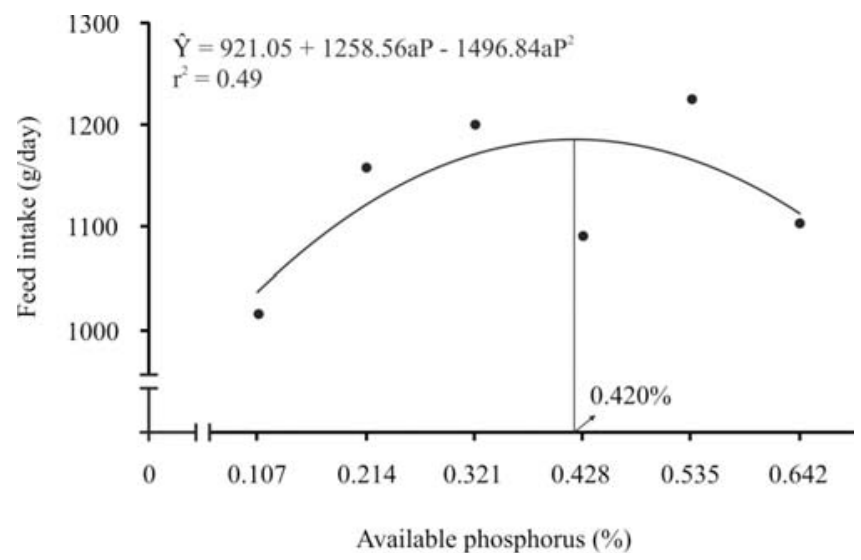

Figure 1 - Effect of aP levels on the feed intake of pigs from 15 to $30 \mathrm{~kg}$ kept in a thermoneutral environment.
Reduction in feed intake at the highest aP level was not enough to compromise daily aP intake which increased $(P<0.01)$ linearly according to the equation $\hat{Y}=-0.0185495$ $+11.4498 \mathrm{aP}\left(\mathrm{r}^{2}=0.99\right)$. A linear increase in aP intake of barrows (from 9 to $37 \mathrm{~kg}$ ) and gilts (from 15 to $30 \mathrm{~kg}$ ) was found by Stahly et al. (2000) and Saraiva et al. (2009).

The effect of the aP levels was also observed $(P<0.01)$ on the average daily gain (Table 2 ), which showed a quadratic behavior up to a maximum response of $0.443 \%$ (Figure 2). This result was consistent with those obtained by Stahly and Cook (1997) and Saraiva et al. (2009), who working with barrows and gilts up to $30 \mathrm{~kg}$ observed that the average daily gain of pigs improved in a quadratic way up to 0.500 and $0.509 \%$ aP, respectively. The positive effects of aP on the growth rates of barrows and gilts from 9 to $37 \mathrm{~kg}$ was also observed by Stahly et al. (2000), who obtained a better response at the level of $0.480 \%$. Although these results are consistent, with respect to the effect of aP levels on the growth rates of pigs, the levels that provided the best results varied among the results. This fact is probably associated, among other factors, to the possible genetic difference of the animals on the growth potential. According to Hittmeier et al. (2006), the genetic potential of pigs can interact with the aP content of the diet, resulting in daily gains that are genotype-specific. This interaction becomes more evident if the aP of the diet is below the requirement of pigs. When intake of phosphorus is limited, pigs with less potential for meat deposition reduce weight as a way of saving phosphorus and keeping bone integrity, whereas pigs with a high potential prioritize muscular growth rather than bone accretion. This genetic specificity related to the use of metabolic phosphorus by pigs, according to these authors, might be associated with differences in the efficiency in which this mineral is absorbed by the intestinal tract and the

Table 2 - Performance, bone parameters and daily carcass protein and fat deposition of pigs fed different levels of available phosphorus $(\mathrm{aP})$

\begin{tabular}{|c|c|c|c|c|c|c|c|}
\hline \multirow[t]{2}{*}{ Item } & \multicolumn{6}{|c|}{ Dietary aP (\%) } & \multirow[t]{2}{*}{ CV (\%) } \\
\hline & 0.107 & 0.214 & 0.321 & 0.428 & 0.535 & 0.642 & \\
\hline Feed intake $(\mathrm{g} / \text { day })^{1}$ & 1016 & 1158 & 1200 & 1091 & 1225 & 1104 & 7.97 \\
\hline aP intake $(g / \text { day })^{2}$ & 1.09 & 2.48 & 3.85 & 4.67 & 6.55 & 7.09 & 9.67 \\
\hline Weight gain $(\mathrm{g} / \text { day })^{1}$ & 492 & 656 & 706 & 685 & 708 & 657 & 9.33 \\
\hline Feed conversion $(\mathrm{g} / \mathrm{g})^{1}$ & 2.07 & 1.77 & 1.70 & 1.59 & 1.74 & 1.69 & 5.18 \\
\hline Bone phosphorus $(\mathrm{g} / \mathrm{kg})^{1}$ & 78.42 & 84.17 & 89.85 & 91.85 & 92.44 & 91.67 & 3.35 \\
\hline Bone calcium $(\mathrm{g} / \mathrm{kg})^{2}$ & 166.67 & 170.00 & 176.83 & 178.17 & 178.00 & 178.00 & 3.76 \\
\hline Bone ash $(\%)^{1}$ & 46.57 & 48.52 & 50.97 & 51.92 & 52.46 & 51.52 & 3.39 \\
\hline \multicolumn{8}{|l|}{ Carcass deposition } \\
\hline Protein $(\mathrm{g} / \text { day })^{1}$ & 60.78 & 84.56 & 97.07 & 80.51 & 86.28 & 72.91 & 12.94 \\
\hline Fat (g/day) & 89.80 & 94.54 & 87.23 & 77.81 & 102.05 & 92.70 & 13.50 \\
\hline
\end{tabular}

10uadratic effect $(P<0.01)$.

${ }^{2}$ Linear effect $(P<0.01)$ 


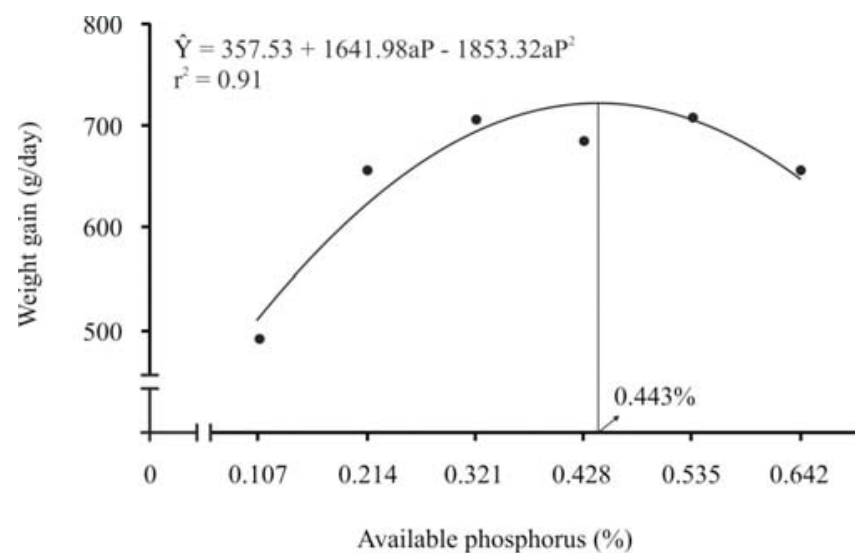

Figure 2 - Effect of aP levels on the weight gain of pigs from 15 to $30 \mathrm{~kg}$ kept in a thermoneutral environment.

level of renal absorption of this nutrient. Confirming this proposition, Alexander et al. (2008), when evaluating aP levels in diets for gilts from two genotypes from 8 to $80 \mathrm{~kg}$, found that plasma levels of hormones associated with organic phosphorus homeostasis maintenance differed not only by phosphorus levels in their diets, but also between the genotypes evaluated.

Levels of aP influenced $(P<0.01)$ feed conversion (Table 2), which improved in a quadratic way up to a maximum response of $0.461 \%$ (Figure 3 ). Similarly, Stahly et al. (2000) and Saraiva et al. (2009) worked with pigs in the initial phase of growth and found that the feed conversion of the animals improved quadratically up to the estimated aP levels of 0.300 and $0.477 \%$, respectively. However, Kegley et al. (2001), evaluating dietary aP levels from 0.16 to $0.40 \%$ in piglets from 6 to $17 \mathrm{~kg}$, found no variation in the feed efficiency utilization for weight gain by increasing aP concentration in the diet.

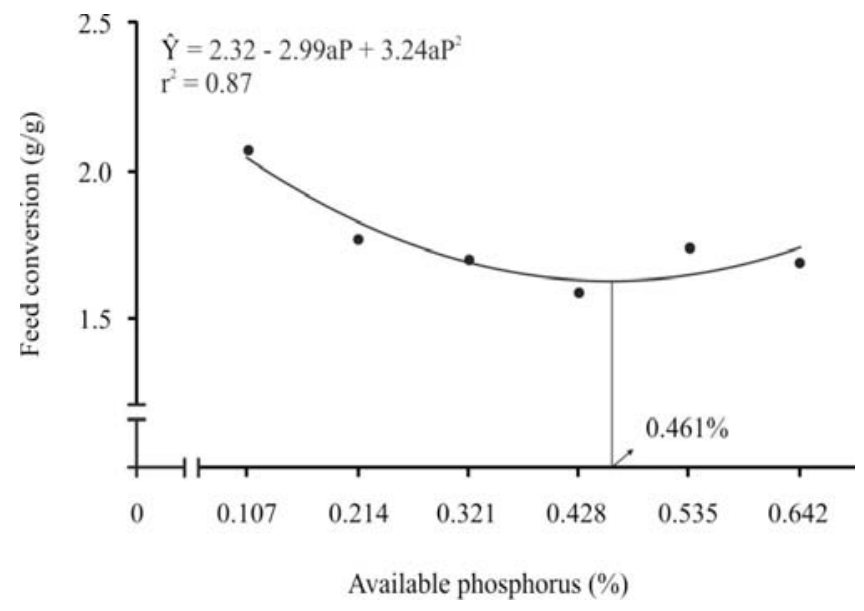

Figure 3 - Effect of aP levels on feed conversion of pigs from 15 to $30 \mathrm{~kg}$ kept in a thermoneutral environment.
Comparing the results of feed conversion and average daily gain obtained in this study, it was found that the aP level that provided the best result for feed conversion $(0.461 \%)$ was greater than the necessary for maximum average daily gain $(0.443 \%)$. These percentages, which correspond to the estimated daily aP intakes of 5.45 and $5.25 \mathrm{~g}$, show that the levels of 0.32 and $0.40 \% \mathrm{aP}$ recommended by the NRC (1998) and Rostagno et al. (2005) might not be sufficient to meet the current genotype of pigs in the initial phase of growth (15 to $30 \mathrm{~kg}$ ).

The amount of phosphorus deposited in the bones was affected $(\mathrm{P}<0.01)$ by the aP levels in diets (Table 2$)$, increasing quadratically up to a maximal response of $0.525 \%$ (Figure 4). A positive correlation between dietary aP and the amount of phosphorus in bones of piglets up to $37 \mathrm{~kg}$ in body weight was also observed by Gomes et al. (1989) and Saraiva et al. (2009).

The amount of calcium in the bones $(\mathrm{CaB})$ increased $(\mathrm{P}<0.01)$ linearly when aP levels in the diets increased (Table 2). However, the discontinuous linear response plateau model was the best fit to the data, estimating $0.359 \%$ aP from which $\mathrm{CaB}$ remained in a plateau (Figure 5). This result is consistent with those of Saraiva et al. (2009) who, investigating aP levels in diets for castrated male and female pigs from 15 to $30 \mathrm{~kg}$, also found a significant increase in the amount of calcium in the bones. Because dietary calcium did not vary among treatments in this study, it can be inferred that the increase in bone calcium deposition by increasing aP levels is indicative of the interdependence in the bone deposition of these two minerals. This hypothesis is corroborated when it was observed in this work that although the Ca:P ratio varied

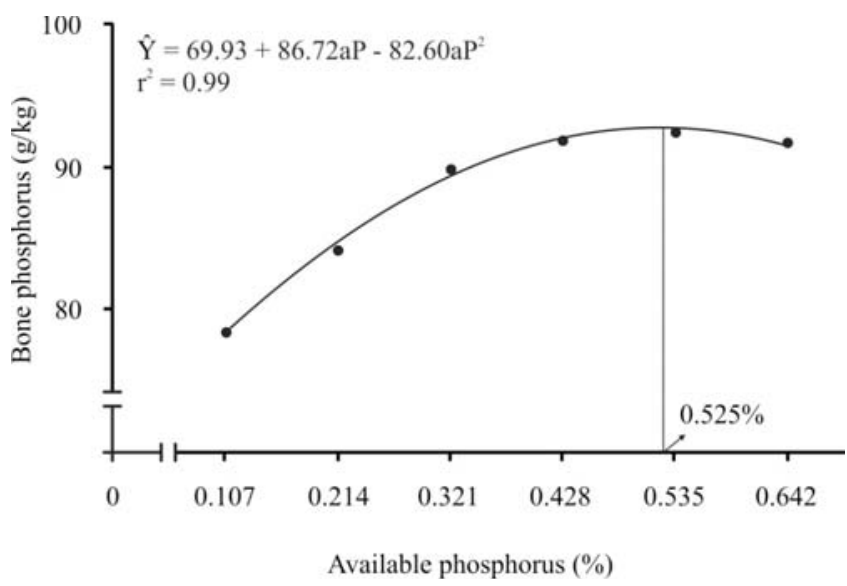

Figure 4 - Effect of aP levels on the amount of phosphorus in the bones of pigs from 15 to $30 \mathrm{~kg}$ kept in a thermoneutral environment. 


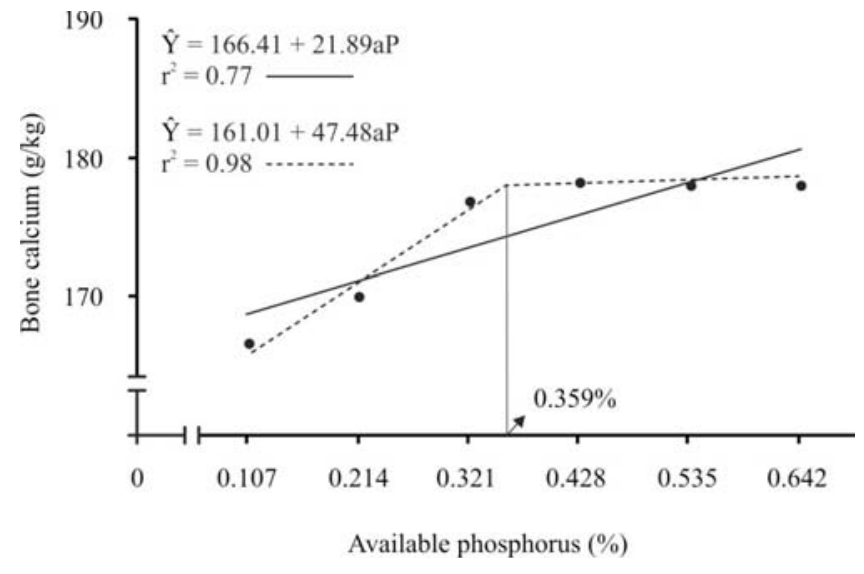

Figure 5 - Effect of aP levels on the amount of calcium in the bones of pigs from 15 to $30 \mathrm{~kg}$ kept in a thermoneutral environment.

from 1.24 to 7.47 , the calculated ratio among the amounts of Ca:P in the bone ranged only from 1.92 to 2.10. Similar results were obtained by Fernandez (1995) with pigs from 35 to $65 \mathrm{~kg}$.

Bone ash percentage was influenced $(P<0.01)$ by aP levels (Table 2), increasing quadratically up to a maximum response of $0.520 \%$ (Figure 6 ). Similar results were found by O’Quinn et al. (1997), Spencer et al. (2000) and Hastad et al. (2004) with pigs at different stages of production.

The results found by this experiment show that the aP levels in the highest bone parameters (bone phosphorus, bone calcium and bone ash) are above the levels that provided the best responses for average daily gain and feed conversion. Different authors (Kornegay et al., 1981; Mahan, 1982; Combs et al., 1991) also found that greater bone mineralization occurred at levels greater than those required to maximize performance of pigs. By contrast, data obtained by Ketaren et al. (1993) showed that the effects of dietary

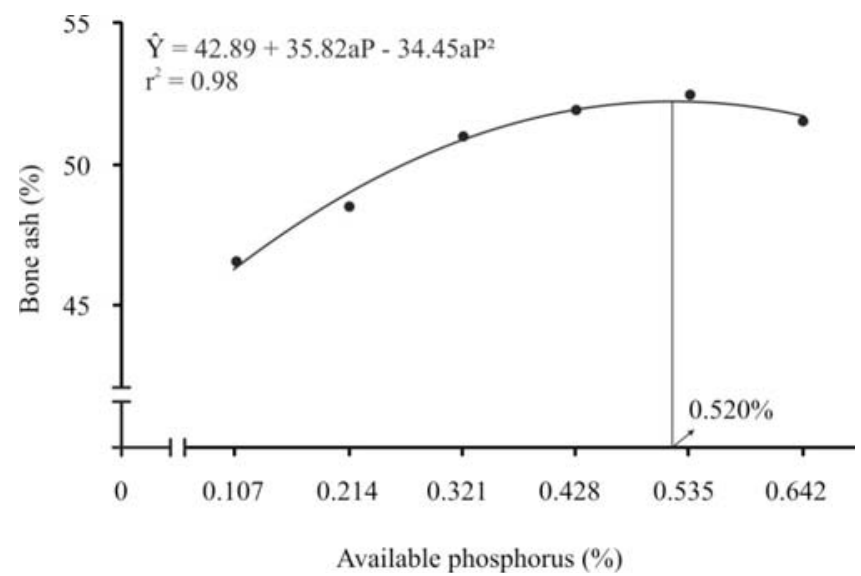

Figure 6 - Effect of aP levels on the bone ash content of pigs from 15 to $30 \mathrm{~kg}$ kept in a thermoneutral environment. phosphorus in the bone ash concentration can vary depending on the bone assessed. In this case, the bone ash content in the radial and femur of the pigs increased linearly, whereas the ash percentage in the metatarsal did not vary with dietary aP levels. Although the phosphorus requirement of pigs for maximum bone mineralization is higher than those required for maximum weight gain and feed conversion (Kornegay et al., 1981; Mahan, 1982; Combs et al., 1991), it has been suggested the formulation of diets that meet the phosphorus requirement of pigs for maximum weight gain or for the best feed conversion (NRC, 1998; Rostagno et al., 2005).

Levels of aP influenced $(P<0.01)$ the daily protein deposition (Table 2), which increased quadratically up to a maximum response of $0.394 \%$ (Figure 7). When assessing dietary aP for piglets from 7 to $23 \mathrm{~kg}$, Frederick and Stahly (1998) observed an increase in the daily protein deposition in the carcasses of pigs by increasing aP up to $0.600 \%$. Despite the similar pattern of response among studies on the increase in the daily protein deposition by increasing dietary aP, it was found that the aP level for maximum daily protein deposition in the present study (0.394\%) was 34\% lower than that obtained by Frederick and Stahly (1998) (0.600\%). However, the calculated Ca:P relationship for the maximum daily protein deposition in those studies was 2.03:1 and 1.92:1, respectively. These results might be indicative of the interdependence of these two minerals also in the protein deposition of pigs, and this can be confirmed by the results of Ca:P ratio found by Fernandez (1995) in the bone tissue, that was close to $2.00: 1$, regardless to dietary Ca:P ratio.

Comparing the results from daily protein deposition with those of average daily gain and feed conversion obtained in this study, it was found that the level that

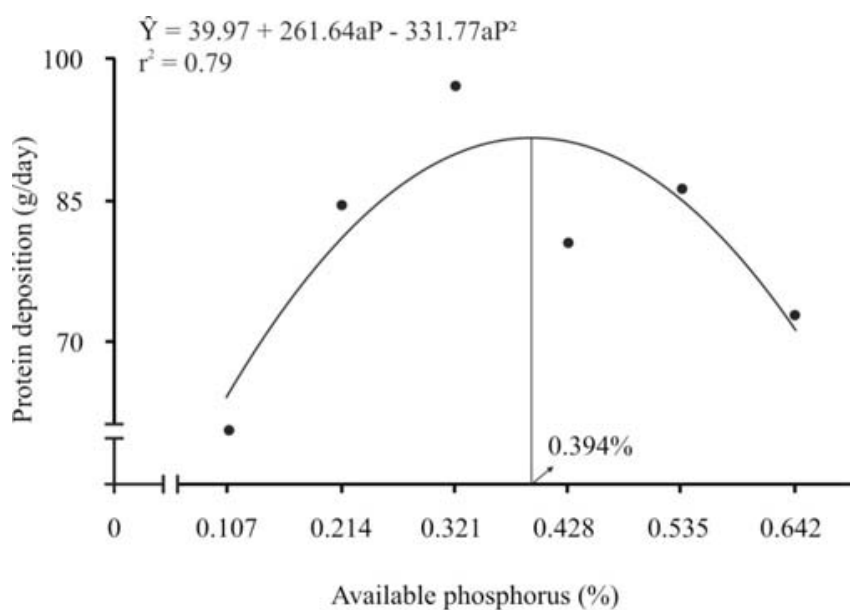

Figure 7 - Effect of aP levels on the protein deposition of pigs from 15 to $30 \mathrm{~kg}$ kept in a thermoneutral environment. 
provided the best result of daily protein deposition $(0.394 \%)$ was lower than that required for maximum average daily gain $(0.443 \%)$ and better feed conversion $(0.461 \%)$. Based on this comparison, the result of daily protein deposition obtained in this study is inconsistent if it is considered that the increase in the protein deposition of pigs is a major factor that can explain the result of increased weight gain together with improved feed conversion (Marinho et al., 2007).

The aP levels did not influence $(P>0.05)$ daily fat deposition (DFD) in the carcass (Table 2). Frederick and Stahly (1998) studied dietary levels of aP for piglets from 7 to $23 \mathrm{~kg}$ and observed that the DFD decreased by increasing aP levels in their diets. Working with pigs during the growing and finishing phases, O'Quinn et al. (1997) and Alexander et al. (2008) reported that dietary aP deficiency resulted in higher fat thickness measured at the $\mathrm{P} 2$ position (10 $\left.{ }^{\text {th }} \mathrm{rib}\right)$. The $\mathrm{aP}$ deficiencies in the referred studies corresponded to 75 and $80 \%$ of the aP levels suggested by the NRC (1998) for both growing and finishing phases.

\section{Conclusions}

The available phosphorus levels of $0.443,0.461$ and $0.525 \%$, corresponding to daily available phosphorus intakes of 5.25, 5.45 and $6.14 \mathrm{~g}$, provide the best results for weight gain, feed conversion and bone parameters, respectively, of pigs from 15 to $30 \mathrm{~kg}$ with a high genetic potential for lean gain kept in a thermoneutral environment.

\section{References}

ALEXANDER, L.S.; QU, A.; CUTLER, S.A. et al. Response to dietary phosphorus deficiency is affected by genetic background in growing pigs. Journal of Animal Science, v.86, p.2585-2595, 2008.

BUFFINGTON, D.E.; COLAZZO-AROCHO, A.; CANTON, G.H. et al. Black globe-humidity index (BGHI) as comfort equation for dairy cows. Transactions of the ASAE, v.24, p.711-714, 1981.

COFFEY, R.D.; PARKER, G.R.; LAURENT, K.M. Feeding growingfinishing pigs to maximize lean grow rate. University of Kentucky. College of Agriculture. Disponível em:<http:// www.animalgenome.org/edu/PIH/prod_grow_finish.pdf $>2000$. Acesso em: 14/5/2007.

COMBS, N.R.; KORNEGAY, E.T.; LINDEMANN, M.D. et al. Calcium and phosphorus requirement of swine from weaning to market weight: II. Development of response curves for bone criteria and comparison of bending and shear bone testing. Journal of Animal Science, v.69, p.682-693, 1991.

CORREA J.A.; FAUCITANO, L.; LAFOREST, J.P. et al. Effects of slaughter weight on carcass composition and meat quality in pigs of two different growth rates Meat Science, v.72, p.91-99, 2006.

DONZELE, J.L.; COSTA, P.M.A.; ROSTAGNO, H.S. et al. Efeito dos níveis de lisina na composição da carcaça de suínos de 5 a $15 \mathrm{~kg}$. Revista da Sociedade Brasileira de Zootecnia, v.21, p.1091-1099, 1992.
FERNÁNDEZ, J.A. Calcium and phosphorus metabolism in growing pigs. II. Simultaneous radio-calcium and radio-phosphorus kinetics. Livestock Production Science, v.41, p.243-254, 1995.

FREDERICK B.R.; STAHLY, T.S. Dietary available phosphorus needs of high lean pigs. ISU Swine Report Research. Iowa State University Extension. Disponível em: <http://www.extension. iastate.edu/Pages/ansci/swinereports/asl-1563.pdf $>1998$. Acesso em: 2/8/2009.

GOMES, P.C.; ROSTAGNO, H.S.; PEREIRA, J.A.A. et al. Exigência de fósforo total e disponível e sua disponibilidade em fosfatos de rochas para suínos na fase incial (13 a $37 \mathrm{~kg}$ ). Revista da Sociedade Brasileira de Zootecnia, v.18, p.64-76, 1989.

HASTAD, C.W.; DRITZ, S.S.; TOKACH, M.D. et al. Phosphorus requirements of growing-finishing pigs reared in a commercial environment. Journal of Animal Science, v.82, p.2945-2952, 2004.

HITTMEIER, L.J.; GRAPES, L.; LENSING, R.L. et al. Genetic background influences metabolic response to dietary phosphorus restriction. Journal of Nutritional Biochemistry, v.17, p.385-395, 2006.

KEGLEY, E.B.; SPEARS, J.W.; AUMAN, S.K. Dietary phosphorus and an inflammatory challenge affect performance and immune function of weanling pigs. Journal of Animal Science, v.79, p.413-419, 2001.

KetAReN, P.P.; BATTERHAM, E.S.; White, E. Phosphorus studies in pig. Available phosphorus requirements of grower/ finisher pigs. British Journal of Nutrition, v.70, p.249-268, 1993.

KORNEGAY, E.T.; THOMAS, H.R.; BAKER, J.L. Phosphorus in swine. IV. Influence of dietary calcium and phosphorus and protein levels on feedlot performance, serum minerals, bone development and soundness scores in boars. Journal of Animal Science, v.52 p.1070-1084, 1981.

MAHAN, D.C. Dietary calcium and phosphorus levels for weanling swine. Journal of Animal Science, v.54, p.559-564, 1982.

MANNO, M.C.; OLIVEIRA, R.F.M.; DONZELE, J.L. et al. Efeito da Temperatura Ambiente sobre o Desempenho de Suínos dos 15 aos 30 kg. Revista Brasileira de Zootecnia, v.34, p.1963-1970, 2005.

MARINHO, P.C.; FONTES, D.O.; SILVA, F.C.O. et al. Efeito da ractopamina e de métodos de formulação de dietas sobre o desempenho e as características de carcaça de suínos machos castrados em terminação. Revista Brasileira de Zootecnia, v.36, p.1061-1068, 2007 (supl.).

NATIONAL RESEARCH COUNCIL - NRC. Nutrient requirements of swine. 9.ed. Washington, D.C.: National Academy of Science, 1998. 189p.

O’QUINN, P.R.; KNABE, D.A.; GREGG, E.J. Digestible phosphorus needs of terminal-cross growing-finishing pigs. Journal of Animal Science, v.75, p.1308-1318, 1997.

REINHARD, G.A.; MAHAN, D.C. Effect of various calcium:phosphorus ratios at low and high dietary phosphorus for starter, grower and finishing swine. Journal of Animal Science, v.63, p.457-466, 1986.

ROSTAGNO, H.S.; ALBINO, L.F.T.; DONZELE, J.L. et al. Tabelas brasileiras para aves e suínos: composição de alimentos e exigências nutricionais. 2.ed. Viçosa, MG: UFV, Imprensa Universitária, 2005. 186p.

SARAIVA, A. DONZELE, J.L.; OLIVEIRA, R.F.M. et al. Available phosphorus levels in diets for swine from 15 to $30 \mathrm{~kg}$ genetically selected for meat deposition. Revista Brasileira de Zootecnia, v.38, p.307-313, 2009.

SHIELDS JUNIOR, R.G.; MAHAN, D.C.; GRAHAM, P.L. Changes in swine body composition from birth to $145 \mathrm{~kg}$. Journal of Animal Science, v.57, p.43-54, 1983.

SILVA, D.J. Análise de alimentos: métodos químicos e biológicos. Viçosa, MG: Universidade Federal de Viçosa, 1990. 166p. 
SPENCER, J.D.; ALLEE, G.L.; SAUBER, T.E. Phosphorus bioavailability and digestibility of normal and genetically modified low-phytate corn for pigs. Journal of Animal Science, v.78, p.675-681, 2000.

STAHLY, T.S.; COOK, D.R. Dietary available phosphorus needs of pigs from 13 to 70 pounds body weight. ISU Swine Report Research. Iowa State University Extension. Disponível em: $<$ http://www.extension.iastate.edu/Pages/ansci/swinereports/asl1477.pdf> 1997. Acesso em: 2/8/2009.

STAHLY, T.S.; LUTZ, T.R.; CLAYTON, R.D. Dietary available phosphorus needs of high lean pigs fed from 9 to $119 \mathrm{~kg}$ body weight. ISU Swine Report Research. Iowa State University Extension. Disponível em: <http://www.ipic.iastate.edu/reports/ 00swinereports/asl-655.pdf $>2000$. Acesso em: 2/8/2009.

STAHLY, T.S. Nutrient needs for high lean pigs. Manitoba agriculture, food and rural initiatives. Disponível em: <http://www.gov.mb.ca/ agriculture/livestock/pork/swine/bab10s13.html> Acesso em: 6/6/2007.

UNDERWOOD, E.J.; SUTTLE, N.F. The mineral nutrition of Livestock. 3.ed. New York: CABI Publishing, 1999. 598p.

UNIVERSIDADE FEDERAL DE VIÇOSA - UFV. SAEG - Sistemas de análises estatísticas e genéticas. Versão 8.0. Viçosa, MG, 2000. (CD-ROM) 